\title{
PROJECT OF MODERNISATION OF THE EDUCATION PROCESS IN SLOVAKIA
}

\section{Vladimír KORMANEC}

\begin{abstract}
The article deals with actual homochronous project of modernization of the primary and secondary educational process in Slovakia. It discusses the process of modernisation so far and reveals particular phases of project. The article outlines the main parts of the project, including its purpose project, its usage in practice.
\end{abstract}

Key words: modernization of educational process, digital literacy, information and communication technologies.

\section{PROJEKT MODERNIZÁCIA VZDELÁVACIEHO PROCESU NA SLOVENSKU}

Resumé: Článok sa zaoberá aktuálne prebiehajúcim projektom Modernizácia vzdelávacieho procesu na Slovensku. Pojednáva o doterajšom priebehu modernizácie a odhal'uje jednotlivé etapy projektu. Článok zachytáva hlavné zložky projektu ako účel projektu, jeho praktickú využitel'nost' a prínos pre súčasné vzdelávanie.

Kl'účové slová: modernizácia vzdelávacieho procesu, digitálna gramotnost', Informačné a komunikačné technológie.

\section{Introduction}

In recent information age with relatively vivid dynamics of IT progress is education with help of ICT more familiar to pupils and students than in traditional forms. The education is complex process, that would have to immediately react to needs of labour market and prepare students for their future career several years later. To support innovation of education started the project called The modernization of educational process (MEP) in Slovakia. MEP as the national project was created in concordance with The operational programme of Education of ministry of education of Slovakia. The modernization is in progress in two projects, mainly for primary secondary and high schools. The main idea is to prepare teachers for implementation of school reform, so adaptation of education to the needs of modern society. Teachers who are interested in improving themselves, are prepared to fulfil the new tasks that brings the modern information school environment. They have the best chance to improve in ICT and its contributional use by teacher's duty.

\section{The goals of the project}

The specific goals of the project are to innovate and modernize the content, methods and outputs of the education process to teach new competencies of work at modern school of the 21 st century. At the same time the goal is to

increase the contribution of teachers participating in programmes of post graduate education based on to reach and to develope their competencies that are necessary for sciental society. The target groups of the project will be more than 6850 teachers of primary secondary and high schools as the primary target group and 347000 pupils of primary secondary and high schools as the secondary target group. The projects have been underway since 2008 to 2013 and their sponzor is The Institute of Information and Prognosis of Education.

\section{The implementation of the project}

The preparation and implementation of this widespread project is complex. It carries a lot of technical and administrative work on the part of teachers and schools. The project itself is divided into several parts. It starts with public acquisition of services and technique required for education. It includes the selection of concrete schools and frequentants for the project of MEP of primary secondary and high schools. For this project was supplied required didactic technique and necessary technical equipment such as: dataprojectors, laptops, computers, interactive boards and so on for selected schools. For education of teachers in MEP it was necessary to create new special didactic and digital educational tools for the use of informationcommunication technologies in education of the 
new national educational programme. Every teacher involved in the project will have access to textbooks, methodics and educational tools in electronic form on project educational portal. These details were designed for 10 subjects of primary and secondary schools (Biology, History, Chemistry, Physics, Mathematics, Geography, Slovak language and literature, Music and Arts) and 7 subjects of high schools (Biology, History, Physics, Geography, Chemistry, Mathematics, Slovak language and literature). The revitalization of teachers of primary secondary and high schools is oriented mainly on development of digital literacy, skills in the field of the use of new didactic technique and on development of their knowledge in the field of the use of ICT in educational process of concrete subjects.

\section{The modules of the project}

MEP will be in progress gradually in three modules. The time frame of the project for all three modules is:

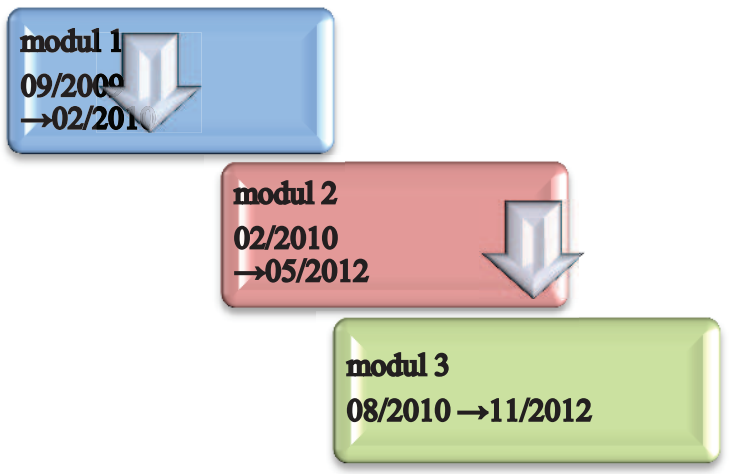

1. The digital literacy of a teacher contains 18 face-to-face lessons and 6 lessons at a distance. It contains the acquisition and following development of digital literacy which includes the development of competencies of teachers in the process of life-long education, revealing questions about internet security and the threats to learners in the virtual environment [1].

The first module discusses more about following topics:

- what is inside in the laptop,

- $\quad$ the usage of instaled software,

- what is necessary for on-line communication,

e-learning and LMS and their usage,

communication within virtual groups,

work with project portal eMEP,

work with a text editor in practice,

work with a spreadsheet,
- $\quad$ creation of multimedial presentations,

- $\quad$ browseing and working with the Internet,

- principles of electronic communication,

- web 2.0 functions, advantages, options,

- the video conferencing systems EVO, ACP

The whole module is accompanied by 79 specific tasks to be demonstrated by which we can attest the level of acquired information. An example of one of the tasks: Find out which shapes you can make by workomg with application whiteboard. Is it possible to write on more boards at the same time?

In the first module teachers have to create 6 online activities. Tasks are the part of e-learning environment to which are after their creation placed and consequently advised by lector. The state of the task is denoted by three words: asked, in progress or complete. The module gives an option to learn the skills with ICT, it will be valued by both beginners and advanced teachers, with its content is structured for excitation of interest even for experienced users of ICT.

2. The modern didactic technique carries 24 lessons of presentation and from that 6 distance lessons. Their goal is to acquaint participants with modern didactic technique and its effective usage in education. Teachers acquaint themselves with didactic work with pictures, animations, graphs, multimedias, sound, photography and music, didactic work with the Internet, didactic control of digital equipment. They learn new forms and options for organizing the educational process [2]. The modul contains work with interactive boards including alternative educational systems and technologies. It demostrates the basics of usage of technique of videoconferences, IPTV solutions, blogs and etc. The second module concretely describes topics such as:

- $\quad$ digital tools for modern teacher

- working with online documents and physical materials

- social networks at work and life of the teacher

- digital work environment of the teacher the classroom

- digital presentation of information

- $\quad$ digital view to microworld

- $\quad$ digital picture, sound and video

- the interactive board, its options and advantages

- $\quad$ the mobility and vizualization for Tablet

- $\quad$ the usage and advantages of E-polling

- the electronic science laboratory 
- GPS in education

- $\quad$ digital music instruments

- wireless technologies and their application in education

The second module describes the latest ICT technologies which can be used not only in education. The difficulty of modules requires previous practical ICT experiences in specific fields what can discourage less experienced teachers.

3. The usage of ICT in specific subjects is the topic of the third module. Module 3 contains 64 lessons and from that 30 face-to-face and 24 lessons at a distance. 10 lessons are designated for the final project. The aim of this module is implementation of acquired teachers knowledge from the first two modules in particular educational subjects and to acquaint with examples of model application of digital content. This module is specifically designed to needs of particular subjects [3]. The portal MEP offers to registered users of the project a variety of educational tools for particular subjects. Teachers can find here:

- $\quad$ software for testbuilding, interactive tasks and exercises,

- $\quad$ a videoguide for interactive board

- $\quad$ editors of digital maps

- flash guides for blogbuilding and work with LMS moodle

- $\quad$ animations, interactive worksheets

- preparations for interactive board in Activestudio programme

- $\quad$ computer supported experiments

In this module the teacher works with a variety of useful software and his activity is based on aspecific subject and its teaching with the help of ICT. For example the teacher of History will learn to work with the editor of historic maps, (s)he will know how to work with digital historic sources and (s)he will design an effective presentation for the lesson. In module (s)he will learn how to use the Xmind application effectively in the History lesson and how to create quality animations. The history teacher will learn how to work with a programme for designing a historic family tree such as Ancestry and Family tree builder. After successful completion of all three modules the teacher will approve his newly acquired skills by writing of a final work (thesis). Every teacher will have a tutor who helps him or her with the writing of the thesis.

\section{The Conclusion}

The project MEP is by its content and purposes extremely important. The project is an example of what is needed to create the strenght slovak educational systsm of the future. The recent evaluation of the first graduates of the project shows a high level of satisfaction and usage in practice. One weakness of the project is the long length of time between particular modules caused by an insufficient number of lecturers in some subjects.

\section{Leterature}

[1] ADÁMEK, R. a kol. Digitálna gramotnost' učitel'a, 1. vyd. Košice: Elfa, 2009. 80 s. ISBN 978-80-8086-119-3.

[2] ADÁMEK, R. a kol. Moderná didaktická technika v práci učitel'a, 1. vyd. Košice: Elfa, 2009. 200 s. ISBN 978-80-8086-119-3.

[3] BRESTESKÁ, B. a kol. Premena školy s využitím informačných a komunikačných technológií, 1. vyd. Košice: Elfa, 2009. 200 s. ISBN 978-80-8086-143-8.

Ing. Vladimír Kormanec

Katedra informačných a komunikačných

technológií

Pedagogická fakulta OSU

Mlýnská 5,

70103 Ostrava 1, ČR

Tel: +421903242072

E-mail: pcart@azet.sk 